\title{
WT1 Enhances Proliferation and Impedes Apoptosis in KRAS Mutant NSCLC via Targeting $c M y c$
}

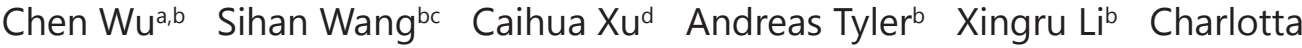 \\ Andersson $^{b, c}$ Yusuke Ojie Haruo Sugiyama ${ }^{f}$ Yijiang Chen ${ }^{g}$ Aihong Li ${ }^{b}$

\begin{abstract}
aDepartment of Tumor Biological Treatment, The Third Affiliated Hospital of Soochow University, Changzhou, China; b,cDepartment of Medical Biosciences, ${ }^{b}$ Clinical Chemistry and 'Pathology, Umeå University, Umeå, Sweden; dDepartment of Cardiovascular Surgery, First Affiliated Hospital of Soochow University, Soochow, China; ${ }^{e}$ Department of Cancer Stem Cell Biology, Osaka University Graduate School of Medicine, Osaka, Japan; 'Department of Functional Diagnostic Science, Osaka University Graduate School of Medicine Osaka, Japan; 9Department of Thoracic and Cardiovascular Surgery, First Affiliated Hospital of Nanjing Medical University Nanjing, China
\end{abstract}

\author{
Key Words \\ KRAS mutation $\bullet$ WT1 $\bullet$ cMyc $・$ NSCLC $\cdot$ Apoptosis
}

\begin{abstract}
Background: A novel link between oncogenic KRAS signalling and WT1 was recently identified. We sought to investigate the role of WT1 and KRAS in proliferation and apoptosis. Methods: KRAS mutations and WT1 ( $C M y c)$ expression were detected using Sanger sequencing and real-time PCR in 77 patients with non-small cell lung cancer (NSCLC). Overexpression and knockdown of WT1 were generated with plasmid and siRNA via transient transfection technology in H1299 and H1568 cells. MTT assay for detection of cell proliferation, and TUNEL assay and proteomic profiler assay for apoptosis evaluation were carried out. Dual luciferase reporter assay and ChIP-PCR were performed to validate the effect of WT1 on the cMyc promoter. Results: KRAS mutations showed a negative impact on overall survival (OS). High expressions of WT1 and $c M y c$ were associated with poor OS in KRAS mutant subgroup. The potential mechanisms that WT1 promotes proliferation and impedes apoptosis through affecting multiple apoptosis-related regulators in KRAS mutant NSCLC cells were identified. WT1 could activate $c M y c$ promoter directly in KRAS mutant cells. Conclusion: The results suggest that WT1 and $c-M Y C$ expression is important for survival in KRAS mutant tumors as opposed to KRAS wild-type tumors. For treatment of KRAS mutant NSCLC, targeting WT1 and cMyc may provide alternative therapeutic strategies.
\end{abstract}




\section{Cellular Physiology and Biochemistry}

Cell Physiol Biochem 2015;35:647-662

DOI: $10.1159 / 000369726$

Published online: January 28, 2015

(c) 2015 S. Karger AG, Basel

www.karger.com/cpb

\section{Introduction}

In lung cancer patients, five-year survival rates still remain low, approximately 10$15 \%$ [1]. Remarkable effort has been made to improve the outcome of these patients and promising results have been achieved using target therapies direct against tumor's driver mutations. Indeed, patients harboring mutations of the epidermal growth factor receptor (EGFR) benefit from treatment with tyrosine kinase inhibitors (TKIs) targeting EGFR [24]. Since KRAS is a downstream target of EGFR, increasing clinical interest has been shown in KRAS mutation as a predictive biomarker for EGFR-targeted therapies. KRAS mutations are present in $15-30 \%$ of NSCLC [5, 6]. Recent clinical trials have demonstrated that KRAS mutant tumors respond poorly to EGFR inhibitor (erlotinib or gefitinib) being a predictor of innate resistance [7-9].

EGFR functions as an upstream activator of RAS. Cell proliferation and survival are regulated by RAS through several pathways including MAPK, STAT and PI3K signaling cascades [10-12]. The Wilms' tumor gene (WT1) was recently found as a key regulator of the genetic network of oncogenic KRAS [13]. However, the precise mechanisms for mutant KRASrelated signaling pathways remain elusive.

At least 24 isoforms of WT1 are generated by a combination of alternative translation start sites, alternative RNA splicing and RNA editing. Exons 5 (a 17-amino-acid insertion) and 9 (inclusion or exclusion of three amino acids, lysine, threonine and serine (KTS)) are subjected to alternative splicing, generating four different major splice isoforms designated as $\mathrm{A}(-/-), \mathrm{B}(+/-), \mathrm{C}(-/+)$ and $\mathrm{D}(+/+)[14]$. These four isoforms are also the best studied. Initially, WT1 was described as a tumor suppressor gene in Wilms' tumor [15]. In clear cell renal carcinoma (ccRCC), we have demonstrated that WT1 can act as a tumor suppressor via multiple pathways leading to downregulation of hTERT [16]. Moreover, WT1 was found to bind directly the promoters of the downstream targets hTERT, cMyc and SMAD3 promoters [16]. Accumulating evidence have demonstrated the function of WT1 as an oncogene in other types of cancers including leukemia and breast cancer (reviewed in [17]). Thus, the WT1 gene was recently proposed to act as a chameleon gene in human malignancies [18].

We have recently reported that WT1 expression was correlated with clinical stage, metastasis, and survival rate in NSCLC patients. By in vitro experiments, we showed that WT1 can promote NSCLC invasion through direct binding to the CDH1 promoter [19]. Furthermore, WT1 was found to promote NSCLC cell proliferation by upregulating Cyclin $\mathrm{D} 1$ and p-pRb expression in vitro and in vivo [20] . The present study aimed to investigate the functional link between WT1, KRAS mutation and a WT1 downstream target $(c M y c)$ in NSCLC. We report our evaluation of three markers in relation to clinical outcome in NSCLC and describe WT1 function in cell proliferation and apoptosis in KRAS mutant cells.

\section{Materials and Methods}

\section{Patient and tissue samples}

The study was performed on a total of 77 NSCLC patients, of which 62 were adenocarcinomas and the remaining 15 specimens were squamous cell carcinomas. These patients were treated at the People's Hospital of Jiangsu Province between September, 2007 and October, 2009. The specimens were collected under a protocol approved by the Human Ethics Committee of Nanjing Medical University. Each patient participated after providing informed consent. The median age of the patients was 68 years (range $54-86$ years) and median survival time was 35.5 months (range 15.5 - 44.0 months).

A total of 154 tissue specimens were included, with one tumor sample and one corresponding adjacent sample (within $3 \mathrm{~cm}$ of the incised margin) for each patient. All fresh tissues were cut into two parts and one was frozen in nitrogen until DNA and RNA extraction, the other was embedded for pathological confirmation. These specimens were histologically classified according to the National Comprehensive Cancer Network (NCCN) guidelines for NSCLC [21]. 


\section{Cellular Physiology and Biochemistry}

Cell Physiol Biochem 2015;35:647-662

DOI: $10.1159 / 000369726$

Published oniıne: January 28, 2015

C) 2015 S. Karger AG, Basel

www.karger.com/cpb

DNA and RNA preparation

DNA and total RNA were prepared from fresh frozen tissues as previously described [16]. cDNA was synthesized using reverse transcriptase kit (TAKARA, Tokyo, Japan).

Real-time quantitative PCR for WT1 and cMyc RNA expression

WT1 and $c M y c$ mRNA levels were measured by RQ-PCR using SYBR Premix Ex Taq (TAKARA, Tokyo, Japan). WT1 transcription values were normalized against the expression of $\beta$-actin to adjust for variations in RNA and cDNA synthesis. Amplification conditions, primers and probes for WT1 were previously described [16]. Standard curves were generated using a series of dilutions of plasmid DNA carrying the WT1 or $\beta$-actin gene with copy numbers from $10^{0}$ to $10^{7}$. The mean of triplicates of the WT1 gene copy numbers was divided by the mean of duplicates of copy numbers of the $\beta$-actin gene. Primers for $c M y c$ were used as previously described [16]. Values of target gene expression were calculated with template and normalized to the $\beta$-actin gene.

\section{Sequence analysis for identification of KRAS mutation}

The primers spanning codon 12 and 13 in exon 2 of the KRAS gene to detect mutation status were used as previously described [22]. Sequence analysis was performed on ABI Prism 3700 DNA Analyzer (Applied Biosystems, Foster City, USA). The derived sequences were identified using GenBank (EMBL) searches (http://www.ncbi.nlm.nih.gov/genbank/).

Cell culture, WT1A and WT1D plasmid and siRNA transfection

NSCLC cell lines, H1299 (CRL-5803 ${ }^{\mathrm{TM}}$ ) and H1568 (CRL-5876 ${ }^{\mathrm{TM}}$, LGC Standards, Middlesex, UK) were employed in transfection experiments. Cells were cultured according to the manufacturer's instructions. The WT1 isoforms A and D have been demonstrated to induce morphological changes in ovarian cancer cells [23] and in osteosarcoma cell lines [24] acting as an oncogene. These isoforms were therefore selected in this study. pcDNA 3.1(+) vectors (Invitrogen) ligating with WT1 variant A or D were constructed as described previously [23]. In order to induce WT1 overexpression, cells were transiently transfected using Lipofectamine 2000 (Invitrogen) with $2 \mu \mathrm{g}$ per well of WT1A or WT1D pcDNA 3.1(+) vectors in six-well plate $\left(1.5 \times 10^{5}\right.$ cells $)$ or with $0.2 \mu \mathrm{g}$ per well of $W T 1 A$ or $W T 1 D$ pcDNA $3.1(+)$ vectors in 96-well plate $(3.0$ $\mathrm{x} 10^{3}$ cells). pcDNA 3.1(+) vector without insert of WT1A or WT1D was used as control. For suppression of WT1 expression, pooled siGENOME SMART pool WT1 siRNA (50nM, Dhamacon, Chicago, USA) was used for transfection. Cells were collected at 24, 48 and 72 hours after transfection for further analysis.

\section{Protein extraction and western blot analysis}

Total proteins were extracted using CHAPS lysis buffer. Protein expressions of WT1 and cMyc were evaluated using western blot as previously described [16]. The antibodies used were the following: WT1 (1 : 500; Dako, Glostrup, Denmark), cMyc (1 : 1000, Cell Signalling Technology Inc. Danvers, MA, USA), Bcl-2 (1 : 1000, Cell Signalling Technology Inc.), $\beta$-actin (1: 10 000, Dako) and peroxidase-conjugated anti-mouse or anti-rabbit antibodies $(1: 5000$, Dako).

\section{MTT assay}

Vybrant MTT Cell Proliferation Assay Kit (Invitrogen) was applied to measure cell proliferation. Cells were collected at 0,24 and 48 hours after WT1 siRNA or plasmid transfection were labeled and incubated with MTT solution, mixed with SDS-HCL. Absorbance was read at $570 \mathrm{~nm}$ on a spectrometer. The experiment was performed in triplicates.

\section{Immunocytochemistry}

Cytospins were prepared from culturing $\mathrm{H} 1299$ and $\mathrm{H} 1568$ cell lines and fixed in acetone for 10 minutes after air drying on slides, blocked with $0.05 \%$ PBST (0.5ml Tween-20 in 1L Phosphate buffer solution) for 20 minutes and treated with hydrogen peroxide for 10 minutes to inactivate endogenous peroxidase. The Ki-67 staining, with monoclonal antibody (1 : 200, Abcam, Cambridge, UK) supplied in its own blocking solution, was performed by a fully automated slide preparation system (Ventana Medical Systems, Arizona, USA). For each slide, 200 cells were analyzed. 


\section{Cellular Physiology and Biochemistry}

Cell Physiol Biochem 2015;35:647-662

DOI: $10.1159 / 000369726$

Published online: January 28, 2015

C) Karger AG, Basel

www.karger.com/cpb

Terminal deoxynucleotidyltransferas dUTP nick end labeling (TUNEL) analysis

TUNEL staining using In Situ Cell Death Detection Kit, TMR red (Roche Diagnostics GmbH, Mannheim, Germany) was performed to detect oligonucleosomal DNA fragmentation. At 48 hours after transfection, cells were fixed in $2 \%$ paraformaldehyde. After permeabilization with $0.1 \%$ Triton X-100 in $0.1 \%$ sodium citrate, cells were stained for DNA strands breaks with TMR red. The staining was analyzed in a FACSCaliburTM flow cytometer using FL3 channel for detection of TMR red (BD Biosciences, San Jose, USA).

\section{Proteomic profiler assay}

The Proteome ProfilerTM Human Apoptotic Array Kit (R\&D System, Oxford, UK) was applied to determine the relative levels of proteins or kinases related to apoptosis. The assay was performed in ChemiDoc XRS System (Bio-Rad) using Quantity One 1-D Analysis Software. 300 $\mu \mathrm{g}$ of proteins were used on each membrane and spots were visualized using chemiluminescent detection system (GE Healthcare).

\section{Luciferase reporter gene assay}

The wild-type and mutant $c M y c$ promoters were cloned using overlap PCR method as previously described [25]. H1299 and H1568 cells were co-transfected using Lipofectamine 2000 (Invitrogen) and the following transfection mix: $250 \mathrm{ng}$ of the reporter plasmid containing promoter response elements, 3 ng of pRL-TK encoding Renilla luciferase cDNA and $500 \mathrm{ng}$ of the pcDNA3 vector either empty as control or containing $W T 1 A$ and $W T 1 D$ variants. Luciferase activity was measured by a dual luciferase reporter assay system (Promega) and the transfection efficiency standardized against Renilla luciferase activity.

\section{Chromatin immunoprecipitation (ChIP) analysis}

ChIPs were performed using the Chromatin Immunoprecipitation Kit (Upstate Millipore, Billerica, MA, USA). Approximately 2 - $3 \times 10^{6}$ cells were cross-linked with $1 \%$ formaldehyde, followed by glycine to quench unreacted formaldehyde. Chromatin was sonicated on ice to shear cross-linked DNA to about $200-1000$ base pairs in length using a Sonifier ultrasonic cell disruptor (Branson, Danbury, CT, USA) with $12 \times 10$ s pulses. The sheared chromatin was resuspended in dilution buffer and $1 \%$ of the chromatin was removed as input, followed by immunoprecipitation using protein $\mathrm{G}$ magnetic beads with $2 \mu \mathrm{g}$ of either anti-WT1 (C-19) antibody (Santa Cruz Biotechnology Inc, Santa Cruz, CA, USA, ) or normal rabbit IgG (Cell Signalling Technology Inc, Danvers, MA, USA) at $4{ }^{\circ} \mathrm{C}$ overnight with rotation. After the reversal of cross-links by incubation in ChIP elution buffer containing proteinase $\mathrm{K}$ at $62^{\circ} \mathrm{C}$ for $2 \mathrm{~h}$, DNA was purified using spin columns.

PCR reactions containing $2 \mu \mathrm{l}$ of the immunoprecipitated DNA or input chromatin, primers and AmpliTaq Gold (Applied Biosystems) in a $50 \mu \mathrm{l}$ volume were performed with initial denaturation at $95^{\circ} \mathrm{C}$ for $10 \mathrm{~min}$, followed by 35 cycles $\left(95^{\circ}\right.$ for $30 \mathrm{~s}, 55^{\circ} \mathrm{C}$ for $30 \mathrm{~s}$ and $72^{\circ} \mathrm{C}$ for $45 \mathrm{~s}$ ) and a final extension at $72^{\circ} \mathrm{C}$ for $10 \mathrm{~min}$. The primer sequences for $c M y c$ promoter were described previously [25]. PCR products were fractionated on $1 \%$ agarose gel, and ethidium bromide stained DNA was visualised on Ultraviolet Transilluminator (Spectroline, Westbury, NY, USA).

SKOV-3 cell line with undetectable endogenous WT1 protein was used as an additional negative control in the experiment.

\section{Immunofluorescence}

H1299 and H1568 cells were seeded at a cell density of $0.5 \times 10^{5}$ cells/cm2, grown on coverslips for 24 hours. Next, they were washed once in PBS, fixed in $4 \%$ formaldehyde, permeabilized with $2 \%$ Triton X-100, and then blocked in 5\% bovine serum albumin. Incubations with anti-WT1 antibodies (1:50, DAKO) and anti-cMyc (1:100, Abcam) were performed overnight at $4^{\circ} \mathrm{C}$. Then, secondary antibodies Alexa Fluor 555 and 488 (Invitrogen) were added. The preparations were mounted with coverslips in mounting medium with DAPI according to the manufacturer's recommendations. Images were captured using a NikonEFD3 microscope (Boyce Scientific, Gray Summit, MO, USA) and Nikon camera (100Eplan [160/0.17] objective, Nikon, Melville, NY, USA).

Statistical analysis

Statistical analysis was performed using SPSS (version 17, SPSS Inc., Chicago, IL, USA). The MannWhitney U-test was used to calculate differences in the expression of two independent variables. Fisher's 
Table 1. KRAS mutations at codon 12 and 13 in 19 NSCLC patients

\begin{tabular}{|c|c|c|c|c|c|c|}
\hline & & NSCL & patients & & & \\
\hline & & Codon & Mutation & Amino acid change & e Number of 1 & atients \\
\hline & & 12 & GGT-TGT & Gly-Cys & 5 & \\
\hline & & 12 & GGT-GAT & Gly-Asp & 6 & \\
\hline & & 12 & GGT-GTT & Gly-Val & 2 & \\
\hline & & 12 & GGT-GCT & Gly-Ala & 1 & \\
\hline & & 13 & GGT-AGT & Gly-Ser & 3 & \\
\hline & & 13 & GGC-GAT & Gly-Asp & 2 & \\
\hline Table 2. Correlation between & Characteristics & & All patients & KRAS mutant & KRAS wild type & $\mathrm{p}$ \\
\hline$K R A S$ mutation status and clini- & $\mathrm{n}$ & & 77 & $19(24.6 \%)$ & $58(75.3 \%)$ & \\
\hline cal and pathologic character- & Age (years) & & & & & 0.352 \\
\hline istics in patients with NSCLC & Median & (range) & $68(54-86)$ & $71 \quad(56-86)$ & $68 \quad(54-86)$ & \\
\hline Pathology Stage was based on & Sex & & & & & 0.539 \\
\hline NCCN (National Comprehen- & & Male & $62(80.5 \%)$ & $15(19.5 \%)$ & $47(61 \%)$ & \\
\hline sive Cancer Network) Guide- & & Female & $15(19.5 \%)$ & $4(5.2 \%)$ & $11(14.3 \%)$ & \\
\hline lines $^{\mathrm{TM}}$ Version 3.2011 Non- & Histology & & & & & 0.867 \\
\hline Small Cell Lung Cancer & Adenoca & cinoma & $55(71.4 \%)$ & $15(19.4 \%)$ & $40(52 \%)$ & \\
\hline & Suqamous cell ca: & cinoma & $20(26 \%)$ & $4(5.2 \%)$ & $16(20.8 \%)$ & \\
\hline & Large cell cat & cinoma & $2(2.6 \%)$ & $0(0 \%)$ & $2(2.6 \%)$ & \\
\hline & Pathological stage & & & & & 0.001 \\
\hline & & IA & $27(35 \%)$ & $4(5.2 \%)$ & $23(29.8 \%)$ & \\
\hline & & IB & $26(33.8 \%)$ & $6(7.8 \%)$ & $20(26 \%)$ & \\
\hline & & IIA & $5(6.5 \%)$ & $1(1.3 \%)$ & $4(5.2 \%)$ & \\
\hline & & IIB & $10(13 \%)$ & $6(7.8 \%)$ & $4(5.2 \%)$ & \\
\hline & & IIIA & $5(6.5 \%)$ & $2(2.6 \%)$ & $3(3.9 \%)$ & \\
\hline & & IIIB & $4(5.2 \%)$ & $0(0 \%)$ & $4(5.2 \%)$ & \\
\hline & $\begin{array}{l}\text { WT1 RNA level } \\
(\text { WT } / \beta \text {-actin } \times 10\end{array}$ & & & & & 0.518 \\
\hline & & Median & 3.48 & 3.15 & 3.78 & \\
\hline & & (range) & $(0.02-11.51)$ & $(0.03-7.58)$ & $(0.02-11.51)$ & \\
\hline & cMyc RNA level & & & & & 0.726 \\
\hline & $(\mathrm{cMyc} / \beta$-actin $\times 1$ & $\left.0^{-3}\right)$ & & & & \\
\hline & & Median & 4.09 & 3.51 & 4.66 & \\
\hline & & (range) & $(0.06-23.64)$ & $(0.17-22.62)$ & $(0.06-23.64)$ & \\
\hline
\end{tabular}

exact tests (when cell size was $<5$ ) were used for comparison of proportions. The $\chi^{2}$ test was used to test the significance of observed differences in proportions. The Kaplan-Meier method was used to estimate the distribution of overall survival (OS). Differences in survival distribution between groups (WT1, cMyc expression level and KRAS mutation status) were compared using the log-rank test.

\section{Results}

Correlation of KRAS mutations with patients' clinical and pathological characteristics in NSCLC

KRAS mutation was identified in 19 of 77 tumor specimens (24.7\%). Single amino acid substitutions in codon 12 were detected in 14 samples, whereas mutations in codon 13 were found in 5 samples (Table 1).

KRAS mutation status and clinical and pathological characteristics in patients were summarized in Table 2. KRAS mutation was less frequently detected in pathological stage I $(\mathrm{p}=0.001)$. No significant differences could be found in patients with and without KRAS mutations with regard to age, sex and histology.

Overexpression of WT1 and cMyc in NSCLC

Significantly higher RNA levels of WT1 and $c M y c$ were detected in tumor specimens with KRAS mutations or KRAS wild-type than their paired adjacent tissues (Fig. 1A and B), 
Fig. 1. Expression of $W T 1$ and $c M y c$ transcripts and correlation between expressions of these two genes in non-small cell lung cancer (NSCLC) patients. A, RNA expression of WT1 in paired tumour and adjacent tissue samples. B, $c M y c$ RNA levels in paired tumour and adjacent tumour free tissues. C, Correlation between RNA expression of WT1 and $c M y c$ in KRAS mutant tumour samples. D, Correlation between RNA expression of WT1 and $c M y c$ in KRAS wild-type tumour samples.
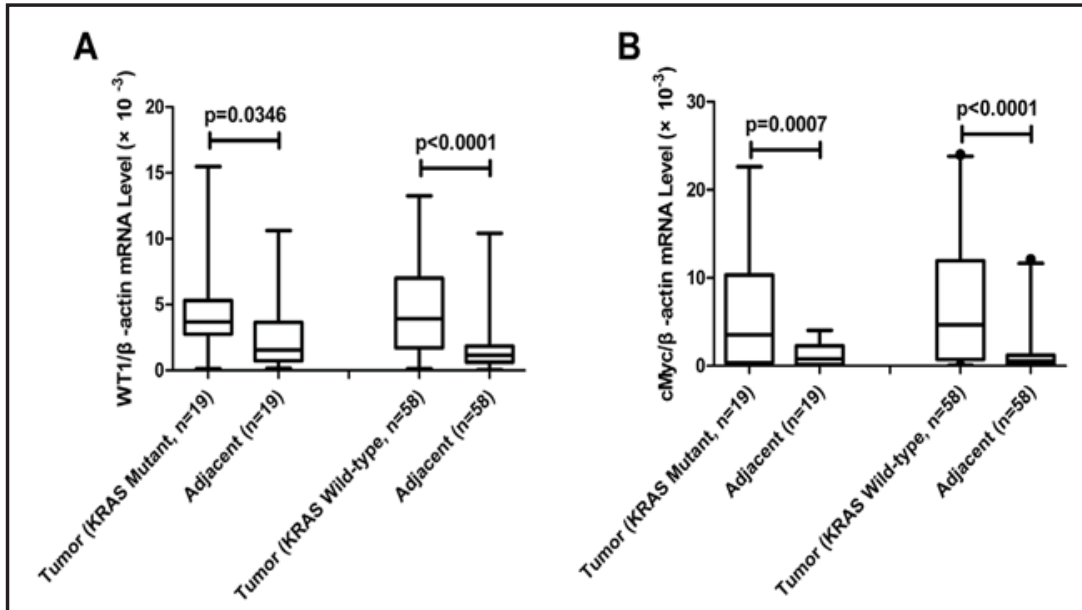

C

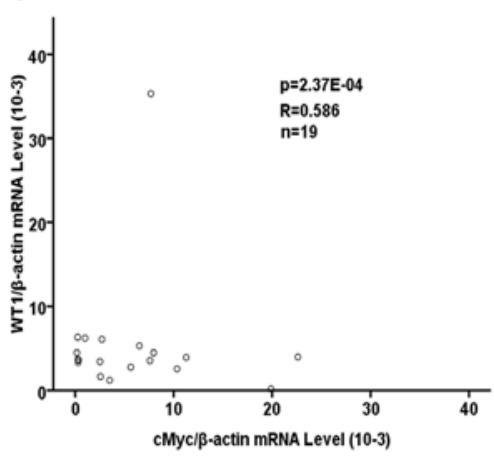

D

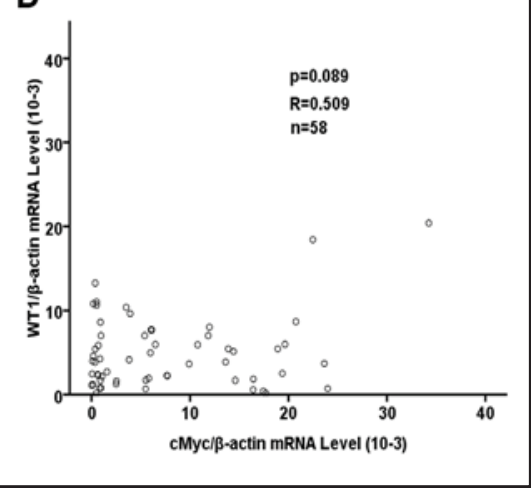

indicating upregulation of both genes in NSCLC. Moreover, a significant correlation was found between WT1 and $c M y c$ in tumor samples with KRAS mutations as shown in Fig. 1C but only a trend in KRAS wild type tumors (Fig. 1D), suggesting a functional link between them may exist in KRAS mutant tumors. It is of note that the coefficiency was mild but it may be explained by some other factors that may affect these gene expressions because both genes act as oncogene in NSCLC in our limited sample materials.

\section{Impact of KRAS mutations, WT1 and cMyc expressions on overall survival}

Patients with KRAS mutant tumors had shorter OS compared to patients with wild-type KRAS ( $\mathrm{p}<0.001$, Fig. 2A). By using cutoffs at a median of $W T 1$ RNA level (median $=3.48$ ) and a median of $c M y c$ RNA level (median $=4.09$ ), patients were divided into subgroups. A poor OS was demonstrated in patients with both KRAS mutation and a high WT1 expression ( $\mathrm{p}=$ 0.008 , Fig. $2 B$ ) but not in patients with wild-type $K R A S(\mathrm{p}=0.347)$. Interestingly, a similar pattern was detected in the $c M y c$ RNA expression subgroup. Survival analysis showed no significant differences in comparison with a cutoff at a median $c M y c$ RNA level in all NSCLC subjects $(\mathrm{p}=0.942)$ or the wild-type KRAS subjects $(\mathrm{p}=0.737)$. However, patients with mutant $K R A S$ and higher $c M y c$ expression had shorter OS compared to those with lower $c M y c$ expression levels ( $\mathrm{p}=0.001$, Fig. $2 \mathrm{C}$ ).

Further analysis was performed combining $W T 1$ and $c M y c$ RNA expression levels. We found that patients with mutant KRAS, and higher WT1 and $c M y c$ expression levels (both > median) had worse OS ( $\mathrm{p}=0.003$, Fig. 2D) but no differences were found in wild-type KRAS patients $(\mathrm{p}=0.515)$. The results indicated that prognosis for clinical outcome was affected by tumors with KRAS mutation itself and together with upregulated WT1 and $c M y c$ RNA expression. 
A

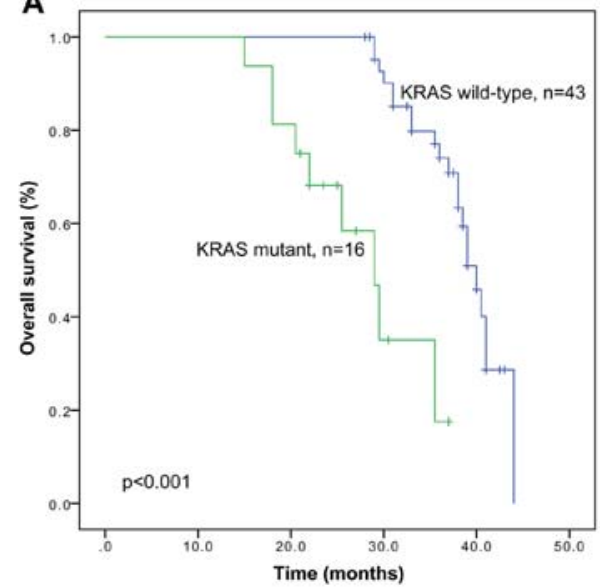

C

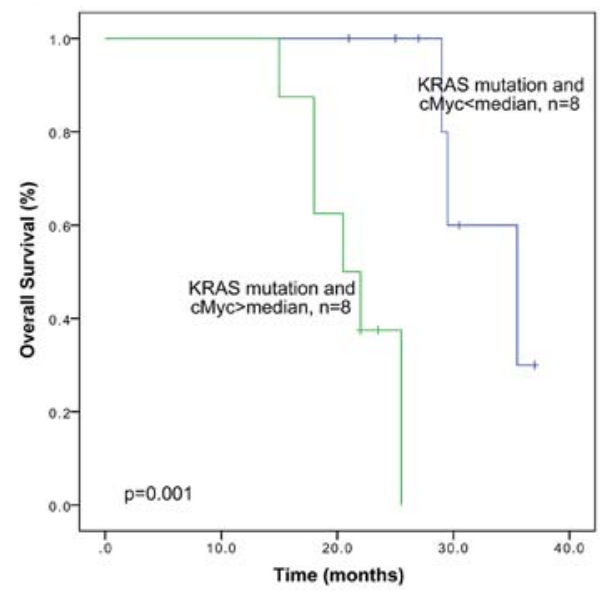

B

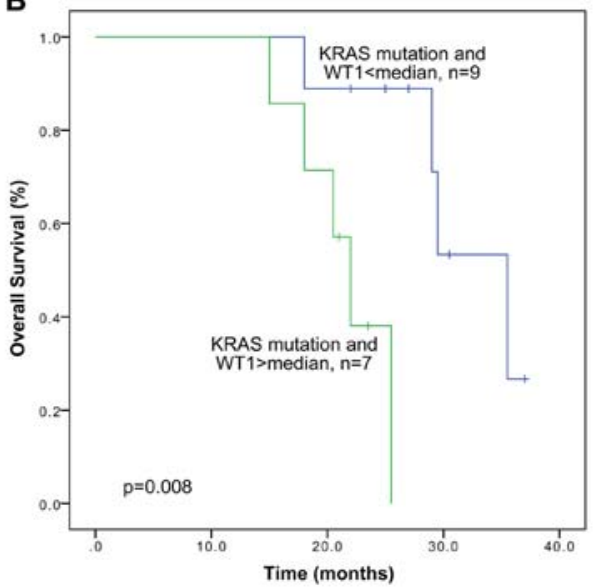

D

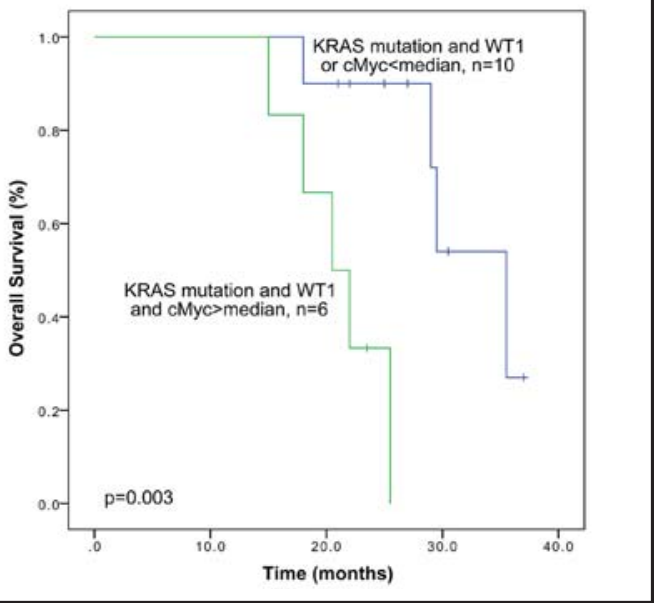

Fig. 2. Impact of KRAS mutations, WT1 and $c M y c$ expressions on overall survival. A, Overall survival (OS) using the Kaplan-Meier analysis in patients with KRAS mutant tumours compared to patients with wild-type KRAS. B, Survival analysis in the subgroup of patients with KRAS mutation and WT1 expression at a cut off with median $\left(3.48 \times 10^{-3}\right)$. C, Survival analysis in the subgroup of patients with KRAS mutation and $c M y c$ RNA expression at a cut off with median $\left(4.09 \times 10^{-3}\right)$. D, Survival analysis in the subgroup of patients with KRAS mutation and both WT1 and $c M y c$ expression levels.

WT1 promotes cell proliferation in KRAS mutant NSCLC cell line

To further investigate the potential mechanism of WT1 and KRAS functions, KRAS mutant cell line H1299 and KRAS wild-type cell line H1568 were used to perform transcriptional experiments. WT1 RNA silencing demonstrated a marked decreased expression of WT1 protein in both cell lines (Fig. 3A). The effect of WT1 silencing on in vitro proliferation was examined using MTT assay. The H1299 cells proliferated at a significantly lower rate with WT1 siRNA compared to control (Fig. 3B). The WT1 silencing did not significantly affect H1568 cell proliferation. Moreover, a cellular marker for proliferation, Ki-67, was stained on both cell lines collected at 48 hours. In H1299 cells, much less positive Ki-67 staining in WT1 siRNA (39\%) was shown compared to control (96\% of cells with positive Ki-67 staining, Fig. 3C). However, both WT1 siRNA and control H1568 cells showed intense staining patterns without marked differences (81\% vs $84 \%$, Fig. 3D).

Additionally, transfection experiments using plasmids carrying WT1 variant A or D was performed to confirm the effect of WT1 and KRAS on cell proliferation. High expression levels of WT1 isoforms A and D were demonstrated in both cell lines (Fig. 3E). Cell proliferation 


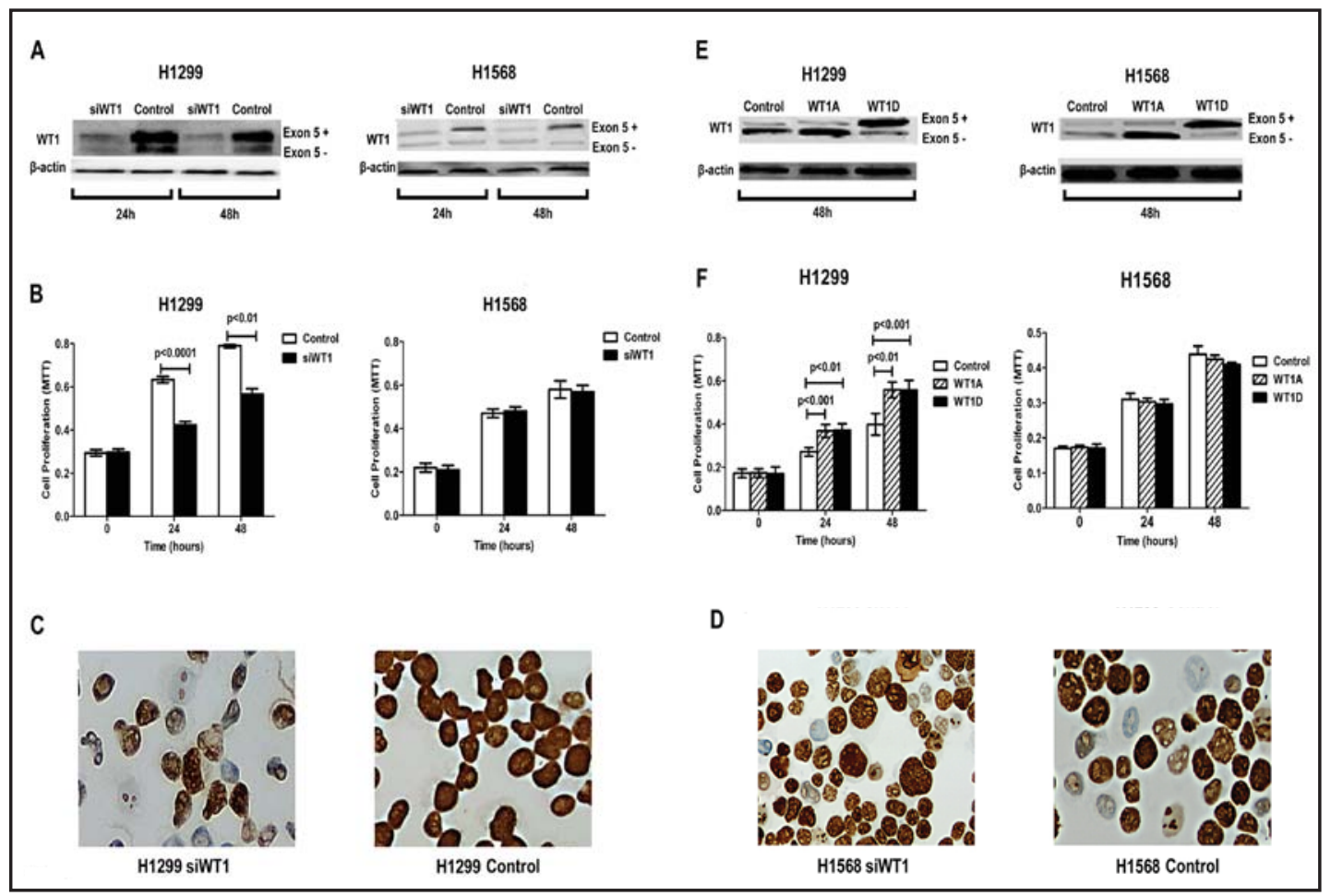

Fig. 3. WT1 affected cell proliferation in the KRAS mutant NSCLC cell line. A, WT1 RNA silencing demonstrated a marked decreased expression of WT1 protein in NSCLC cell lines H1299 (KRAS mutant) and H1568 (KRAS wild-type) at 24 and 48 hours after transfection. B, The effect of WT1 silencing on cell proliferation was examined using MTT assay in H1299 cells and in H1568. C, Ki-67 positive staining in SiWT1 (39\%) and in control (96\%) in H1299. Cells were collected at 48 hours after transfection. D, Ki-67 positive staining in SiWT1 (81\%) and in control (84\%) in H1568. Cells were collected at 48 hours after transfection. E, The effect of WT1 on cell proliferation by transfection experiments using plasmids carrying WT1 variant A (-/-) or D (+/+). WT1 isoforms A and D were presented at 48 hours after transfection in both H1299 and H1568 cell lines. F, Effect on cell proliferation by forced overexpression of WT1 in H1299 and H 1568 cells.

Fig. 4. WT1 RNA silencing induced apoptosis in KRAS mutant NSCLC cells. Cells were collected at 48 hours after transfection. A, TUNEL analysis in KRAS mutant H1299 cells and $\mathrm{B}$ in KRAS wildtype H1568 cells.

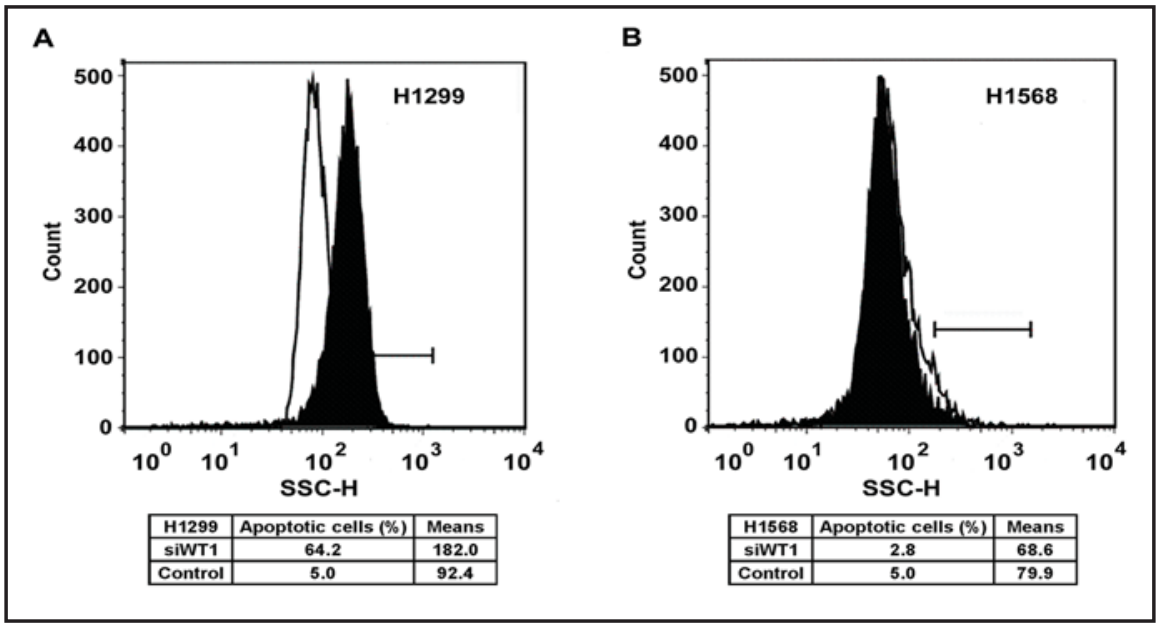

was significantly increased in H1299 cells compared to control but not in H1568 cells (Fig. $3 \mathrm{~F})$. These results indicated that WT1 promotes cell proliferation in KRAS mutant tumors but not in KRAS wild-type. 


\section{Cellular Physiology and Biochemistry}

Cell Physiol Biochem 2015;35:647-662

DOI: $10.1159 / 000369726$

Publisned on Ine: January 28, 2015

Wu et al: A Functional Link Between WT1 and KRAS Mutant NSCIC
Table 3. Silencing WT1 induced fold changes in the expression of apoptosis-related regulator genes by proteome profiler analysis in $\mathrm{H} 1299$ and H1568 cells** Statistical significance $(\mathrm{p}<0.01) .{ }^{*}$ Statistical significance $(\mathrm{p}<0.05)$

\begin{tabular}{|c|c|c|c|}
\hline \multirow[t]{2}{*}{ Gene name } & \multirow[t]{2}{*}{ Expected effect on apoptosis } & \multicolumn{2}{|c|}{$\begin{array}{l}\text { Fold change } \\
\text { (vs control) }\end{array}$} \\
\hline & & H1299 & H1568 \\
\hline FasTNFSF6 & Activator & $1.408^{* *}$ & 1.01 \\
\hline Cleaved caspase 3 & Activator & $1.309^{*}$ & 1.046 \\
\hline ProCaspase 3 & Activator & 1.176 & 1.068 \\
\hline SMACDiablo & Activator & 1.168 & 0.973 \\
\hline HO1HMOX1HSP32 & Activator & 1.089 & 1.169 \\
\hline Bax & Activator & 0.998 & 0.974 \\
\hline Phosphop53S15 & Activator & 0.996 & 1.066 \\
\hline TRAILR2DR4 & Activator & 0.935 & 1.006 \\
\hline P21CIPCDNK1A & Activator & 0.921 & 1.08 \\
\hline Bad & Activator & 0.91 & 0.97 \\
\hline HTRAOMi & Activator & 0.901 & 1.09 \\
\hline Cytokromc & Activator & 0.894 & 1.196 \\
\hline Phosphop53S46 & Activator & 0.892 & 1.08 \\
\hline Phosphop53\$392 & Activator & 0.891 & 1.065 \\
\hline TRAILR2DR5 & Activator & 0.84 & 1.195 \\
\hline FADD & Activator & $0.716^{*}$ & 1.075 \\
\hline TNFRITNFRSF1A & Activator & 0.645 & 1.028 \\
\hline Bclx & Suppressor & 1.079 & 1.265 \\
\hline PON2 & Suppressor & 0.947 & 1.056 \\
\hline HSP70 & Suppressor & 0.917 & 1.175 \\
\hline HSP27 & Suppressor & 0.896 & 1.098 \\
\hline HIF1a & Suppressor & 0.848 & 1.078 \\
\hline P27Kip1 & Suppressor & 0.845 & 1.102 \\
\hline Livin & Suppressor & 0.816 & 0.982 \\
\hline Survivin & Suppressor & $0.698^{*}$ & 1.064 \\
\hline Clusterin & Suppressor & $0.694^{*}$ & 1.186 \\
\hline Catalase & Suppressor & 0.637 & 1.036 \\
\hline XIAP & Suppressor & $0.622^{* *}$ & 1.071 \\
\hline CIAP2 & Suppressor & $0.573^{*}$ & 1.097 \\
\hline cIAP1 & Suppressor & $0.503^{* * *}$ & 1.003 \\
\hline $\mathrm{Bcl}-2$ & Suppressor/Activator & $1.215^{*}$ & $0.771^{*}$ \\
\hline HSP60 & Suppressor/Activator & 0.937 & 1.031 \\
\hline HO2HMOX2 & Suppressor/Activator & 0.926 & 1.169 \\
\hline PhosphoRad17S63S & Suppressor/Activator & 0.829 & 1.019 \\
\hline Claspin & Suppressor/Activator & $0.746^{*}$ & 1.157 \\
\hline
\end{tabular}

Fig. 5. Bcl-2 expression using western blot analysis in WT1 knock-down cells using silencing WT1 (SiWT1) RNA compared to controls in H1299 and H1568.

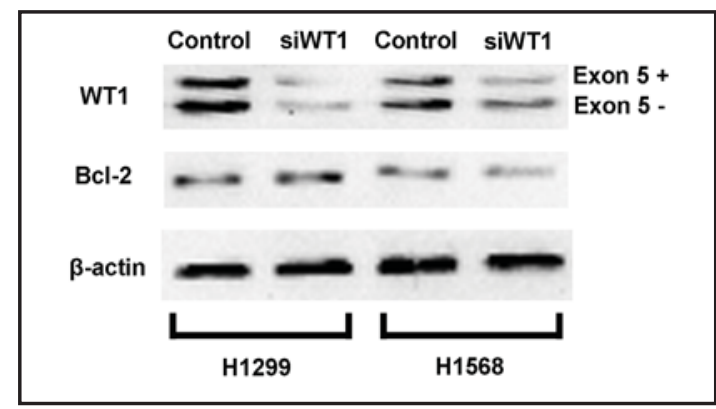

WT1 RNA silencing induces apoptosis in KRAS mutant NSCLC cells

Using TUNEL analysis, WT1 RNA silencing induced an increased apoptotic cell population in H1299 cells (64.2\%) compared to controls (5.0\%, Fig. 4A), whereas in H1568 cells, WT1 siRNA and control did not differ noticeably and showed only a small apoptotic cell population (2.8\% for WT1 siRNA and 5.0\% for control, Fig. 4B).

Furthermore, a total of 35 genes related to apoptosis were analyzed using human apoptotic protein array. Altered protein expressions were significantly changed in WT1 knock-down cells in 10 out of the 35 apoptosis related genes in $\mathrm{H} 1299$ cells but only one gene in H1568 cells compared to their controls (Table 3). In H1299 cells, two positive regulators, 


\section{Cellular Physiology Cell Physiol Biochem 2015;35:647-662 and Biochemistry \begin{tabular}{l|l} 
DOI: 10.1159/000369726 \\
Published onine: January 28, 2015 & $\begin{array}{l}\text { O 2015 S. Karger AG, Basel } \\
\text { www.karger.com/cpb }\end{array}$ \\
\cline { 2 - 3 }
\end{tabular} \\ Wu et al.: A Functional Link Between WT1 and KRAS Mutant NSCLC}

Fig. 6. WT1 can directly increase $c M y c$ promoter activity and bind to the $c M y c$ promoter WT1 binding cite in KRAS mutant NSCLC cells. A, Luciferase reporter gene assay in the two cell lines H1299 and H1568 together with transfection experiments. The WT1A and WT1D cDNA expression plasmids were each cotransfected with $c M y c$ construct (wild or mutant type). Cells were collected at 48 hours after transfection. The value obtained by control transfection was arbitrarily set at 1. The results were shown with the fold change in luciferase activity of experimental cells versus control cells. Means

A

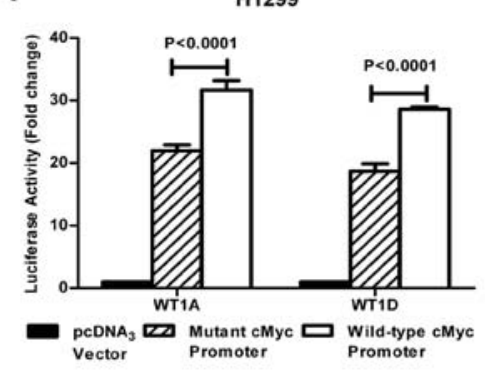

B
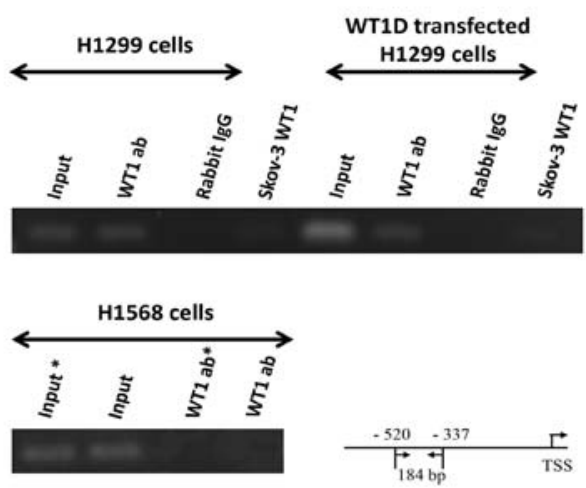

C

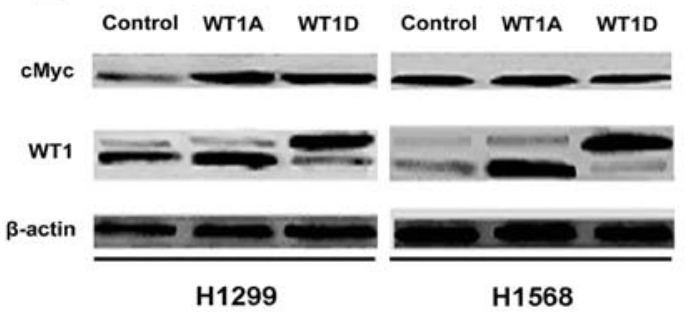

E

H1299
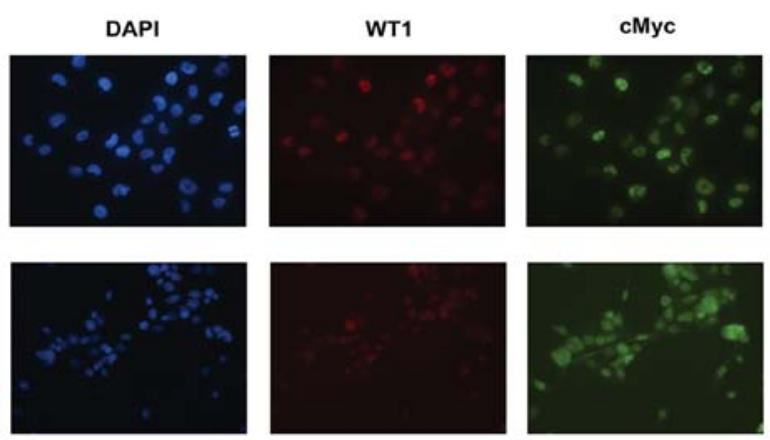

and $95 \%$ confidence interval were calculated after at least three independent transfections. B, DNA binding of WT1 protein to the $c M y c$ promoter. The location and size for each PCR product are illustrated on the right. TSS, transcriptional start site. *, WT1D transfected in H1568 cells. C, cMyc protein expression by western blot in WT1A and WT1D transfected H1299 and H1568 cells. Cells were collected at 48 hours after transfection. D. Decreased expression of cMyc by western blot in H1299 cells but not in H1568 cells after WT1 RNA silencing. Cells were collected at 48 hours after transfection. E, Predominant nuclear localization of endogenous WT1 (red) and endogenous cMyc (green) by double-immunofluorescence in H1299 and H1568 cells. Nuclei were visualized by DAPI (blue) staining. 


\section{Cellular Physiology and Biochemistry}

Cell Physiol Biochem 2015;35:647-662

DOI: 10.1159/000369726

Published onlıne: January 28, 2015

C) 2015 S. Karger AG, Basel

www.karger.com/cpb

FasTNFSF6 and cleaved Caspase 3, were significantly upregulated. Five negative regulators, including Survivin, Clusterin, XIAP, cIAP2 and cIAP1, and one positive regulator, FADD, demonstrated decreased expression. Alterations in two dual function genes were shown as decreased expression of Claspin and increased expression of Bcl-2. In contrast, decreased Bcl-2 expression was shown in $\mathrm{H} 1568$ cells. Alteration of Bcl-2 expression at protein level was also verified using western blot analysis (Fig. 5). The results demonstrated that WT1 has a potential antiapoptotic function through affecting multiple regulators in KRAS mutant cells.

The cMyc gene is a target of WT1 in KRAS mutant NSCLC cells

A positive correlation between $W T 1$ and $c M y c$ expression was presented in clinical NSCLC KRAS mutant tumor specimens as described above. To demonstrate the functional link between $W T 1$ and $c M y c$, we performed luciferase reporter gene assay. Plasmids carrying WT1A or WT1D variants were each cotransfected with $c M y c$ construct. As shown in Fig. 6A, the ability of WT1 to activate the $c M y c$ promoter was observed in H1299 cells but not in H1568 cells. To further demonstrate that the WT1 protein binds directly to the promoters of the $c M y c$ gene, we performed ChIP experiments. As shown in Fig. 6B, a single band was observed when chromatin from H1299 cells and WT1D transfected H1299 cells were immunoprecipitated with WT1 antibody. This was not observed in negative controls when rabbit IgG antibody and SKOV-3 cell line were used. In H1568 cells and WT1D transfected H1568 cells, no specific band could be shown compared to negative control. Using ChIP/ PCR, we could demonstrate direct binding of WT1 to the $c M y c$ promoter in H1299 cells but not in H1568 cells. Western blot showed upregulated cMyc protein in WT1A and D transfected H1299 cells compared to control and no differences in expression of cMyc in H1568 cells (Fig. 6C). Additional experiments were performed to validate the effect of WT1 on $c M y c$ using WT1 RNA silencing. Decreased expression of cMyc was shown in H1299 but not in H1568 compared to their controls (Fig. 6D). The results demonstrated that the $c M y c$ promoter is a target of the WT1 protein in KRAS mutant cells. Double immunofluorescences were performed, showing predominant nuclear localization of WT1 and cMyc in H1299 and H1568 cells (Fig. 6E).

\section{Discussion}

In the present study, KRAS mutation was less frequently detected in stage I tumors and patients with KRAS mutation had shorter OS compared to those with wild-type KRAS. A meta-analysis performed by Huncharek et al. has previously reported that KRAS mutation was associated with shortened survival in NSCLC [26]. A strong association between KRAS mutation and decreased survival in NSCLC patients was demonstrated by Nelson et al. and the correlation was specifically significant for patients diagnosed with stage I tumors [27]. These findings indicate that KRAS mutation analysis can be used as a prognostic molecular marker. Recent studies have shown that NSCLC patients with KRAS mutations are resistant to TKIs and have significantly poorer outcome $[9,28]$ and suggest that KRAS mutation should be added to the panel of resistance markers for EGFR-TKIs in NSCLC [5]. This is supported by a recent meta-analysis showing that KRAS codon 13 mutation is associated with a poorer response to adjuvant CT [29]. However, Tsao et al. found that KRAS mutation status had no prognostic impact on survival or benefits from adjuvant chemotherapy [30]. Mutations in KRAS did not significantly affect outcome in EGRF wild-type NSCLC patients, according to Jackman et al. [31].

Overexpression of WT1 was demonstrated in $96 \%$ of de novo NSCLC [32]. Interestingly, low WT1 expressions predicted poor OS in the entire cohort and a shorter disease-free survival in a subgroup of patients with stage III and IV NSCLC [33]. In this study, WT1 overexpression had a significant negative effect on OS in patients with mutant KRAS tumors but not in wild-type KRAS tumors. Our data suggest that WT1 may affect tumor progression only in KRAS mutant tumors. 


\section{Cellular Physiology and Biochemistry}

Cell Physiol Biochem 2015;35:647-662

\begin{tabular}{l|l}
\hline DOI: $10.1159 / 000369726$ & (C) 2015 S. Karger AG, Basel
\end{tabular}

www.karger.com/cpb

Wu et al.: A Functional Link Between WT1 and KRAS Mutant NSCLC

The $c M y c$ gene has been studied as a proto-oncogene in human malignancies. Overexpression of $c M y c$ was shown in human lung cancer cell lines [34]. A recent study found that progressive lung cancer could be identified by several genetic pathways, including a myc-centered transcription network [35]. We demonstrated that $c M y c$ was overexpressed in NSCLC tumor specimens and high $c M y c$ expression in KRAS mutant tumors had negative correlation with OS. The collected data support the hypothesis that altered myc signaling is involved in disease progression. Considering the limited patient material, the survival analysis in this study was exploratory and our results need to be confirmed in larger study populations.

Using in vitro experiments, we found that cell proliferation decreased due to loss of WT1 in KRAS mutant tumor cells. Forced overexpression of WT1 in KRAS mutant tumor cells induced significantly increased cell proliferation. Wagner et al. showed that inhibition of WT1 reduces cell proliferation, migration and vascular formation through transcriptional activation of the proto-oncogene ETS-1 [36]. A combination strategy of WT1 gene silencing and chemotherapeutic agents cisplatin and doxorubicin was found to have a synergistic effect on inhibiting cell proliferation in B16F10 murine melanoma cells [37]. In human melanoma, WT1 protein expression was found to be associated with shorter overall survival[38]. Treatment using PS-341 (Bortezomib) on a megakaryoblastic cell line was able to retain NF-kB, inhibit cell growth and downregulate WT1 expression [39]. Reduction of WT1 RNA copies was tested in vitro as a predictor of sensitivity to imatinib in chronic myelogenous leukemia [40]. Thus, a compound that downregulates WT1 expression would be of great interest in the treatment of KRAS mutant NSCLC.

WT1 is known to be a transcriptional factor involved in the regulation of apoptosis and cell cycle progression (reviewed in $[17,41]$ ). In the present study, WT1 silencing induced a higher apoptotic cell population. This effect was observed only in KRAS mutant NSCLC cells. However, a study by Vicent $S$ et al. did not show any difference in apoptosis using a group of NSCLC cell lines with and without KRAS mutation including H1299 and H1568. Furthermore, we demonstrated significant fold changes in multiple apoptosis-related genes using proteomic profiler assay. In KRAS mutant cells, the WT1 generated effect on the process of apoptosis seemed complex, as WT1 silencing caused reduced expression of several negative regulators such as Survivin, Clusterin, XIAP, cIAP2, and cIAP1. The expression levels of potential positive regulators, such as FasTNFSF6 and cleaved Caspase 3, were increased. The Bcl-2 gene was significantly upregulated and the expression of Claspin was decreased. These results suggested that the WT1 gene contributes to suppression of apoptosis by affecting multiple apoptosis-related genes. Consistent with our findings, Zamora-Avila et al. demonstrated that loss of WT1 protein expression increased caspase-3 and poly-ADPribose polymerase activity, as well as apoptotic body formation, chromatin condensation and DNA fragmentation in the B16F10 murine melanoma cell line [42]. Algar et al. found that WT1 antisense nucleotide reduced cell proliferation, induced apoptosis and abrogated WT1 protein expression in myeloid leukemia cell lines [43]. By shRNA-targeted knockdown of WT1, resistant leukemia cells were sensitized to the cancer therapeutic agent tumor necrosis factor $\alpha$-related apoptosis-inducing ligand (TRAIL) to TRAIL-induced cell death [44]. The serin protease HtrA2 was identified to be able to cleave WT1 at multiple sites and was shown to be an important regulator of WT1 under proapoptotic conditions, such as cytotoxic drug treatment [45]. The collected data suggest that WT1 has an antiapoptotic function and acts an oncogene in some tumors as described above. In combination with cytotoxic drugs, targeting WT1 may provide a novel therapeutic alternative against cancer cells resistant to regular chemotherapy treatment.

It is known that oncogenic KRAS can lead to either cellular senescence under high oncogene signaling conditions or tumorigenesis when the negative feedback loops are blocked as reviewed in Collado [46]. WT1 was recently identified as a critical regulator of senescence and proliferation downstream of oncogenic KRAS signaling [13]. In a mouse model of KRAS-driven lung cancer, loss of WT1 decreased tumor burden and led to senescence of mouse primary cells expressing physiological level of oncogenic RAS [13]. These effects 


\section{Cellular Physiology and Biochemistry}

Cell Physiol Biochem 2015;35:647-662

DOI: 10.1159/000369726

Published onIne: January 28, 2015

(c) 2015 S. Karger AG, Basel

www.karger.com/cpb

Wu et al.: A Functional Link Between WT1 and KRAS Mutant NSCLC

were also found in human lung cancer cell lines. Furthermore, WT1 high signature could be used to stratify lung cancer patients that express KRAS signature genes into a poor prognostic subgroup [13]. In accordance with their findings, our observations of clinical data showed patients with high expression of WT1 and KRAS mutation had shorter survival time. In vitro experiments, cell proliferation and apoptosis were notably affected in only KRAS mutant NSCLC cells. However, the precise molecular mechanisms for mutant KRASrelated WT1 function remain unclear. Further studies are needed to find how WT1 regulates mutant KRAS-driven oncogenic function. Since RAS proteins have proven difficult to use as a direct therapeutic target, a recent phase 2 study on NSCLC patients with KRAS mutant tumors assessed the compound selumetinib, targeting RAS downstream effecter MEK with promising efficacy but a higher number of adverse events [47]. Therefore, WT1 may provide a new indirect target to inhibit RAS-induced oncogenesis.

A previous study demonstrated that WT1 can bind to the GC-rich Egr1 site (5'-GNGNGGGNG-3') in the cMyc promoter [25]. The WT1 binding site near the second major transcription start site just upstream of nucleotides -107 and +36 was extensively involved in the regulation of $c M y c$ [25]. Studies of WT1 effect on the $c M y c$ promoter have given divergent results, including stimulatory function in breast cancer [25] and suppressive function in ccRCC [16]. Vicent et al. demonstrated that the experimentally derived independent gene sets for $M y c$ pathway genes were upregulated in KRAS mutant tumors compared with control and enrichment of Myc target genes was further found to be up-regulated in KRAS mutant tumors, suggesting a role of Myc as a possible target of WT1 in KRAS mutant cells [13]. Using cMyc-promoter-driven luciferase constructs and ChIP-PCR, we confirmed in this study that WT1 can directly bind to $c M y c$ promoter and act as a positive regulator of $c M y c$ in KRAS mutant NSCLC. Using small molecule inhibitor of MYC-MAX heterodimerization, 10058-F4, cell death was efficiently induced in myeloma cell lines as well as primary myeloma cells [48]. 10058-F4-induced apoptosis and differentiation could also be observed in acute myeloid leukemia [49]. Taken together, an indirect approach by targeting $c M y c$ may be a therapeutic alternative in KRAS mutant NSCLCs.

In summary, we found a correlation between overexpression of WT1, cMyc and poor survival in NSCLC patients with KRAS mutation. The results indicated that measuring WT1 and $c M y c$ expression may serve as useful biomarkers to identify subgroups with KRAS mutation for individualized therapy. Furthermore, in vitro experiments demonstrated that in KRAS mutant cells, WT1 promotes cell proliferation and has antiapoptotic function by affecting multiple apoptosis-related genes and by directly targeting the $c M y c$ promoter. In agreement with findings by Vicent et al. [13], our results support the hypothesis that WT1 acts as a key regulator and as an oncogene in KRAS mutant NSCLC. Together with previous studies on therapeutic alternatives [47-50], this study suggests that WT1 and $c M y c$ may be useful targets in KRAS mutant NSCLCs. These findings may warrant further investigation on the effects of WT1 and $c M y c$ inhibitors in vitro and in vivo.

\section{Disclosure Statement}

None declared.

\section{Acknowledgements}

We thank Professor Beichen Sun and colleagues in Liver Transplantation Center ofFirst Affiliated Hospital of Nanjing Medical University for technique assistance. The authors declare no conflict of interest. This study was supported by the Children's Cancer Foundation in Sweden (PROJ 05/084), the Lion's Cancer Research Foundation, Umeå, Sweden (AMP 10649), the County Council of Västerbotten, Umeå, Sweden (ALF 7000468 and 218401). 


\section{Cellular Physiology and Biochemistry}

Cell Physiol Biochem 2015;35:647-662

DOI: $10.1159 / 000369726$

Published online: January 28, 2015

S. Karger AG, Base

www.karger.com/cpb

\section{References}

1 Rosell R, Felip E, Taron M, Majo J, Mendez P, Sanchez-Ronco M, Queralt C, Sanchez JJ, Maestre J: Gene expression as a predictive marker of outcome in stage iib-iiia-iiib non-small cell lung cancer after induction gemcitabine-based chemotherapy followed by resectional surgery. Clin Cancer Res 2004;10:4215s-4219s.

-2 Maemondo M, Inoue A, Kobayashi K, Sugawara S, Oizumi S, Isobe H, Gemma A, Harada M, Yoshizawa H, Kinoshita I, Fujita Y, Okinaga S, Hirano H, Yoshimori K, Harada T, Ogura T, Ando M, Miyazawa H, Tanaka T, Saijo Y, Hagiwara K, Morita S, Nukiwa T: Gefitinib or chemotherapy for non-small-cell lung cancer with mutated egfr. N Engl J Med 2010;362:2380-2388.

-3 Mitsudomi T, Morita S, Yatabe Y, Negoro S, Okamoto I, Tsurutani J, Seto T, Satouchi M, Tada H, Hirashima T, Asami K, Katakami N, Takada M, Yoshioka H, Shibata K, Kudoh S, Shimizu E, Saito H, Toyooka S, Nakagawa K, Fukuoka M: Gefitinib versus cisplatin plus docetaxel in patients with non-small-cell lung cancer harbouring mutations of the epidermal growth factor receptor (wjtog3405): An open label, randomised phase 3 trial. Lancet Oncol 2010;11:121-128.

4 Mok TS, Wu YL, Thongprasert S, Yang CH, Chu DT, Saijo N, Sunpaweravong P, Han B, Margono B, Ichinose Y, Nishiwaki Y, Ohe Y, Yang JJ, Chewaskulyong B, Jiang H, Duffield EL, Watkins CL, Armour AA, Fukuoka M: Gefitinib or carboplatin-paclitaxel in pulmonary adenocarcinoma. N Engl J Med 2009;361:947-957.

-5 Massarelli E, Varella-Garcia M, Tang X, Xavier AC, Ozburn NC, Liu DD, Bekele BN, Herbst RS, Wistuba, II: Kras mutation is an important predictor of resistance to therapy with epidermal growth factor receptor tyrosine kinase inhibitors in non-small-cell lung cancer. Clin Cancer Res 2007;13:2890-2896.

-6 Marks JL, Broderick S, Zhou Q Chitale D, Li AR, Zakowski MF, Kris MG, Rusch VW, Azzoli CG, Seshan VE, Ladanyi M, Pao W: Prognostic and therapeutic implications of egfr and kras mutations in resected lung adenocarcinoma. J Thorac Oncol 2008;3:111-116.

7 Singh M, Lima A, Molina R, Hamilton P, Clermont AC, Devasthali V, Thompson JD, Cheng JH, Bou Reslan H, Ho CC, Cao TC, Lee CV, Nannini MA, Fuh G, Carano RA, Koeppen H, Yu RX, Forrest WF, Plowman GD, Johnson L: Assessing therapeutic responses in kras mutant cancers using genetically engineered mouse models. Nat Biotechnol 2010;28:585-593.

-8 Troiani T, Schettino C, Martinelli E, Morgillo F, Tortora G, Ciardiello F: The use of xenograft models for the selection of cancer treatments with the egfr as an example. Crit Rev Oncol Hematol 2008;65:200-211.

-9 Eberhard DA, Johnson BE, Amler LC, Goddard AD, Heldens SL, Herbst RS, Ince WL, Janne PA, Januario T, Johnson DH, Klein P, Miller VA, Ostland MA, Ramies DA, Sebisanovic D, Stinson JA, Zhang YR, Seshagiri S, Hillan KJ: Mutations in the epidermal growth factor receptor and in kras are predictive and prognostic indicators in patients with non-small-cell lung cancer treated with chemotherapy alone and in combination with erlotinib. J Clin Oncol 2005;23:5900-5909.

10 Downward J: Signal transduction. New exchange, new target. Nature 1998;396:416-417.

11 Shields JM, Pruitt K, McFall A, Shaub A, Der CJ: Understanding ras: 'It ain't over 'til it's over'. Trends Cell Biol 2000;10:147-154.

12 Vojtek AB, Der CJ: Increasing complexity of the ras signaling pathway. J Biol Chem 1998;273:19925-19928.

13 Vicent S, Chen R, Sayles LC, Lin C, Walker RG, Gillespie AK, Subramanian A, Hinkle G, Yang X, Saif S, Root DE, Huff V, Hahn WC, Sweet-Cordero EA: Wilms tumor 1 (wt1) regulates kras-driven oncogenesis and senescence in mouse and human models. J Clin Invest 2010;120:3940-3952.

14 Haber DA, Sohn RL, Buckler AJ, Pelletier J, Call KM, Housman DE: Alternative splicing and genomic structure of the wilms tumor gene wt1. Proc Natl Acad Sci U S A 1991;88:9618-9622.

15 Haber DA, Buckler AJ, Glaser T, Call KM, Pelletier J, Sohn RL, Douglass EC, Housman DE: An internal deletion within an 11p13 zinc finger gene contributes to the development of wilms' tumor. Cell 1990;61:1257-1269.

-16 Sitaram RT, Degerman S, Ljungberg B, Andersson E, Oji Y, Sugiyama H, Roos G, Li A: Wilms' tumour 1 can suppress htert gene expression and telomerase activity in clear cell renal cell carcinoma via multiple pathways. Br J Cancer 2010;103:1255-1262.

17 Yang L, Han Y, Suarez Saiz F, Minden MD: A tumor suppressor and oncogene: The wt1 story. Leukemia 2007;21:868-876.

18 Huff V: Wilms' tumours: About tumour suppressor genes, an oncogene and a chameleon gene. Nat Rev Cancer 2011;11:111-121.

19 Wu C, Zhu W, Qian J, He S, Chen Y, Shu Y: Wt1 promotes invasion of nsclc via suppression of cdh1. J Thorac Oncol 2013;8:1163-1169. 


\section{Cellular Physiology and Biochemistry}

Cell Physiol Biochem 2015;35:647-662

DOI: $10.1159 / 000369726$

2015 S. Karger AG, Basel

www.karger.com/cpb

Wu et al.: A Functional Link Between WT1 and KRAS Mutant NSCLC

20 Xu C, Wu C, Xia Y, Zhong Z, Liu X, Xu J, Cui F, Chen B, Roe OD, Li A, Chen Y: Wt1 promotes cell proliferation in non-small cell lung cancer cell lines through up-regulating cyclin d1 and p-prb in vitro and in vivo. PLoS One 2013;8:e68837.

21 Greene F, Balch C, Haller D, Morrow M: Ajcc cancer staging manual (6th edition). Springer, 2002.

-22 Lehman TA, Scott F, Seddon M, Kelly K, Dempsey EC, Wilson VL, Mulshine JL, Modali R: Detection of k-ras oncogene mutations by polymerase chain reaction-based ligase chain reaction. Anal Biochem 1996;239:153-159.

23 Jomgeow T, Oji Y, Tsuji N, Ikeda Y, Ito K, Tsuda A, Nakazawa T, Tatsumi N, Sakaguchi N, Takashima S, Shirakata T, Nishida S, Hosen N, Kawakami M, Tsuboi A, Oka Y, Itoh K, Sugiyama H: Wilms' tumor gene wt1 $17 \mathrm{aa}(-) / \mathrm{kts}(-)$ isoform induces morphological changes and promotes cell migration and invasion in vitro. Cancer Sci 2006;97:259-270.

-24 Burwell EA, McCarty GP, Simpson LA, Thompson KA, Loeb DM: Isoforms of wilms' tumor suppressor gene (wt1) have distinct effects on mammary epithelial cells. Oncogene 2007;26:3423-3430.

-25 Han Y, San-Marina S, Liu J, Minden MD: Transcriptional activation of c-myc proto-oncogene by wt1 protein. Oncogene 2004;23:6933-6941.

26 Huncharek M, Muscat J, Geschwind JF: K-ras oncogene mutation as a prognostic marker in non-small cell lung cancer: A combined analysis of 881 cases. Carcinogenesis 1999;20:1507-1510.

27 Nelson HH, Christiani DC, Mark EJ, Wiencke JK, Wain JC, Kelsey KT: Implications and prognostic value of k-ras mutation for early-stage lung cancer in women. J Natl Cancer Inst 1999;91:2032-2038.

28 Pao W, Wang TY, Riely GJ, Miller VA, Pan Q Ladanyi M, Zakowski MF, Heelan RT, Kris MG, Varmus HE: Kras mutations and primary resistance of lung adenocarcinomas to gefitinib or erlotinib. PLoS Med 2005;2:e17.

29 Shepherd FA, Domerg C, Hainaut P, Janne PA, Pignon JP, Graziano S, Douillard JY, Brambilla E, Le Chevalier T, Seymour L, Bourredjem A, Le Teuff G, Pirker R, Filipits M, Rosell R, Kratzke R, Bandarchi B, Ma X, Capelletti M, Soria JC, Tsao MS: Pooled analysis of the prognostic and predictive effects of kras mutation status and kras mutation subtype in early-stage resected non-small-cell lung cancer in four trials of adjuvant chemotherapy. J Clin Oncol 2013;31:2173-2181.

-30 Tsao MS, Aviel-Ronen S, Ding K, Lau D, Liu N, Sakurada A, Whitehead M, Zhu CQ, Livingston R, Johnson DH, Rigas J, Seymour L, Winton T, Shepherd FA: Prognostic and predictive importance of p53 and ras for adjuvant chemotherapy in non small-cell lung cancer. J Clin Oncol 2007;25:5240-5247.

-31 Jackman DM, Miller VA, Cioffredi LA, Yeap BY, Janne PA, Riely GJ, Ruiz MG, Giaccone G, Sequist LV, Johnson $\mathrm{BE}$ : Impact of epidermal growth factor receptor and kras mutations on clinical outcomes in previously untreated non-small cell lung cancer patients: Results of an online tumor registry of clinical trials. Clin Cancer Res 2009;15:5267-5273.

-32 Oji Y, Miyoshi S, Maeda H, Hayashi S, Tamaki H, Nakatsuka S, Yao M, Takahashi E, Nakano Y, Hirabayashi H, Shintani Y, Oka Y, Tsuboi A, Hosen N, Asada M, Fujioka T, Murakami M, Kanato K, Motomura M, Kim EH, Kawakami M, Ikegame K, Ogawa H, Aozasa K, Kawase I, Sugiyama H: Overexpression of the wilms' tumor gene wt1 in de novo lung cancers. Int J Cancer 2002;100:297-303.

33 Hayashi S, Oji Y, Kanai Y, Teramoto T, Kitaichi M, Kawaguchi T, Okada M, Sugiyama H, Matsumura A: Low wilms' tumor gene expression in tumor tissues predicts poor prognosis in patients with non-small-cell lung cancer. Cancer Invest 2012;30:165-171.

-34 Little CD, Nau MM, Carney DN, Gazdar AF, Minna JD: Amplification and expression of the c-myc oncogene in human lung cancer cell lines. Nature 1983;306:194-196.

35 Han N, Dol Z, Vasieva O, Hyde R, Liloglou T, Raji O, Brambilla E, Brambilla C, Martinet Y, Sozzi G, Risch A, Montuenga LM, Brass A, Field JK: Progressive lung cancer determined by expression profiling and transcriptional regulation. Int J Oncol 2012;41:242-252.

-36 Wagner N, Michiels JF, Schedl A, Wagner KD: The wilms' tumour suppressor wt1 is involved in endothelial cell proliferation and migration: Expression in tumour vessels in vivo. Oncogene 2008;27:3662-3672.

-37 Zapata-Benavides P, Manilla-Munoz E, Zamora-Avila DE, Saavedra-Alonso S, Franco-Molina MA, TrejoAvila LM, Davalos-Aranda G, Rodriguez-Padilla C: Wt1 silencing by rnai synergizes with chemotherapeutic agents and induces chemosensitization to doxorubicin and cisplatin in b16f10 murine melanoma cells. Oncol Lett 2012;3:751-755.

-38 Garrido-Ruiz MC, Rodriguez-Pinilla SM, Perez-Gomez B, Rodriguez-Peralto JL: Wt 1 expression in nevi and melanomas: A marker of melanocytic invasion into the dermis. Journal of cutaneous pathology 2010;37:542-548. 


\section{Cellular Physiology and Biochemistry}

Cell Physiol Biochem 2015;35:647-662

\begin{tabular}{l|l}
\hline DOI: $10.1159 / 000369726$ & (C) 2015 S. Karger AG, Basel
\end{tabular}

Wu et al.: A Functional Link Between WT1 and KRAS Mutant NSCLC

-39 Galimberti S, Canestraro M, Pacini S, Fazzi R, Orciuolo E, Trombi L, Mattii L, Battolla B, Capodanno A, Collecchi P, Veroni F, Simi P, Piaggi S, Casini A, Petrini M: Ps-341 (bortezomib) inhibits proliferation and induces apoptosis of megakaryoblastic mo7-e cells. Leuk Res 2008;32:103-112.

40 Cilloni D, Messa F, Gottardi E, Fava M, Arruga F, Defilippi I, Carturan S, Messa E, Morotti A, Giugliano E, Rege-Cambrin G, Alberti D, Baccarani M, Saglio G: Sensitivity to imatinib therapy may be predicted by testing wilms tumor gene expression and colony growth after a short in vitro incubation. Cancer 2004;101:979-988.

-41 Scharnhorst V, van der Eb AJ, Jochemsen AG: Wt1 proteins: Functions in growth and differentiation. Gene 2001;273:141-161.

42 Zamora-Avila DE, Franco-Molina MA, Trejo-Avila LM, Rodriguez-Padilla C, Resendez-Perez D, ZapataBenavides P: Rnai silencing of the wt1 gene inhibits cell proliferation and induces apoptosis in the b16f10 murine melanoma cell line. Melanoma Res 2007;17:341-348.

43 Algar EM, Khromykh T, Smith SI, Blackburn DM, Bryson GJ, Smith PJ: A wt1 antisense oligonucleotide inhibits proliferation and induces apoptosis in myeloid leukaemia cell lines. Oncogene 1996;12:10051014.

44 Bansal H, Seifert T, Bachier C, Rao M, Tomlinson G, Iyer SP, Bansal S: The transcription factor wilms tumor 1 confers resistance in myeloid leukemia cells against the proapoptotic therapeutic agent trail (tumor necrosis factor alpha-related apoptosis-inducing ligand) by regulating the antiapoptotic protein bcl-xl. J Biol Chem 2012;287:32875-32880.

45 Hartkamp J, Carpenter B, Roberts SG: The wilms' tumor suppressor protein wt1 is processed by the serine protease htra2/omi. Mol Cell 2010;37:159-171.

46 Collado M, Serrano M: Senescence in tumours: Evidence from mice and humans. Nature reviews Cancer 2010;10:51-57.

-47 Janne PA, Shaw AT, Pereira JR, Jeannin G, Vansteenkiste J, Barrios C, Franke FA, Grinsted L, Zazulina V, Smith P, Smith I, Crino L: Selumetinib plus docetaxel for kras-mutant advanced non-small-cell lung cancer: A randomised, multicentre, placebo-controlled, phase 2 study. Lancet Oncol 2013;14:38-47.

48 Holien T, Vatsveen TK, Hella H, Waage A, Sundan A: Addiction to c-myc in multiple myeloma. Blood 2012;120:2450-2453.

49 Huang MJ, Cheng YC, Liu CR, Lin S, Liu HE: A small-molecule c-myc inhibitor, 10058-f4, induces cellcycle arrest, apoptosis, and myeloid differentiation of human acute myeloid leukemia. Exp Hematol 2006;34:1480-1489.

50 Vita M, Henriksson M: The myc oncoprotein as a therapeutic target for human cancer. Semin Cancer Biol 2006;16:318-330. 